\title{
OBITUARY
}

\section{Charles Bernard Goulden}

Charles Bernard Goulden was born at Canterbury, of Huguenot stock. His immediate ancestors had returned to the Roman Catholic faith, and he was educated at St. Edmund's College, Old Hall, near Ware and at Downing College, Cambridge. He continued his medical education at the Middlesex Hospital where he won the Freeman Scholarship. After being house surgeon at the Middlesex he decided to take up ophthalmology and entered Moorfields Eye Hospital (R.L.O.H.). Three years of experience at Moorfields found him ready to start in pri-

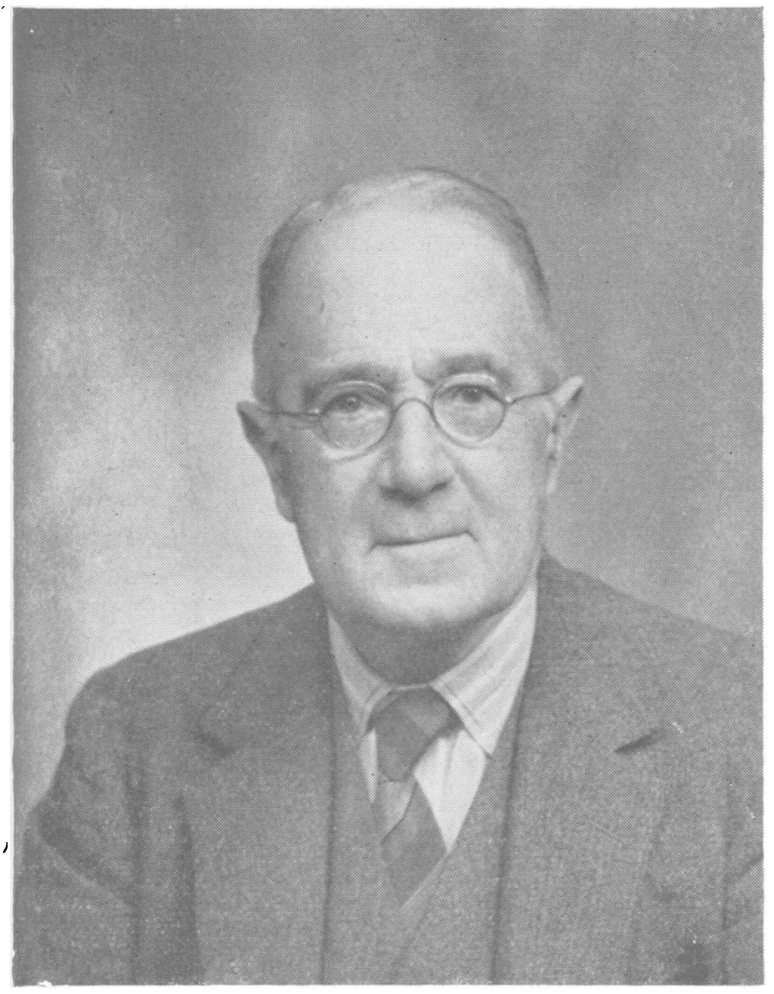

CHARLES BERNARD GOULDEN vate practice but he spent one year at Bristol as Demonstrator of Anatomy.

In 1908 he began to practise in Oldham, where he was appointed Ophthalmic Surgeon to the Royal Infirmary. He was still there at the beginning of the 1914-18 war and did most useful work in the organization of the Red Cross in that area from 1914-16. He would not enter the R.A.M.C. unless he could be accepted for ophthalmic work since he felt that this would be his most useful service. Consequently he did not receive a commission until the middle of 1916 when he was appointed to the 13th Stationary Hospital, Boulogne, then the chief eye centre in France, just before the beginning of the Somme offensive. The hospital contained fifty ophthalmic beds, which soon increased to seventy and later to 120 , and its own operating theatre. Here Goulden found an adequate sphere for his energy, and under Colonel, afterwards Sir William, Lister, contributed a large share to the great volume of work done there. This was the writer's first acquaintance with Goulden, except for a brief chance encounter at a dinner given to William Lang about 4 years before, and it was the beginning of 2 years' war work together.

Charles Goulden was an invaluable and delightful colleague, helpful and sympathetic in all difficulties, but determined and persistent when his experience indicated that some particular course was right. Differences of opinion there might be but never serious disagreements. 
Work was not the only activity which engaged his attention during this period. Music had always been a passion with Goulden, in fact he once said that it was his chief interest in life and that he did eyes for a living, and so it was quite in character that at the Hospital he got up a male voice choir which performed most successfully under his leadership and in which he seemed to have the knack of making men with good voices but little musical sense put up a good performance. However hard-worked the hospital was he generally managed to get in at least one choir practice a week and it was always well attended. What this meant as a relief to the constant strain of dealing with the neverceasing stream of casualties can hardly be imagined.

After 2 years he was put in charge of the ophthalmic work at Rouen, an appointment he felt bound to accept since it was a definite and well-earned promotion, though he left Boulogne with regret. He remained at Rouen until the end of the war.

On returning to England he was persuaded by Lister to give up his practice at Oldham and come to London, where he was appointed to the staff at Moorfields and ophthalmic surgeon at the London Hospital. His work in both hospitals was of a most distinguished character, and his share, a major one, in the introduction of the slit-lamp and the institution of slit-lamp instruction at Moorfields was particularly valuable. With characteristic thoroughness he spent some weeks with Vogt at Zürich in order to prepare the slit-lamp instruction courses at Moorfields.

He succeeded Hepburn as Dean of the School and his work in organizing post-graduate instruction was most successful. He was himself a good teacher, both in his clinic and in the lecture room, since he always insisted on a thorough mastery of the subject and he also possessed that slightly dogmatic outlook which characterizes some of the best teachers. He retired from Moorfields in 1939 but soon came back again in order to do the work of younger men serving with the forces. Added to this was a very considerable volume of advisory work for the Ministry of Health and the Emergency Medical Service, work which no one could have done so well, for his knowledge of the men available and the needs of the areas was unrivalled.

At the end of the war it was a fitting recognition of his distinction and achievement in ophthalmology when he was elected President of the Ophthalmological Society of the United Kingdom, 1945-6. His presidential address on Purkinje was but one example of his keen interest in history, both scientific and general. It is sad for his friends to reflect that when the war was over and he might have looked forward to years of quiet enjoyment in retirement at Shepreth he should have had to undergo two major operations for conditions which not only hastened his death but must have made the last few years difficult and burdensome. But visiting him at the delightful Mill House which was his home and meeting him at the O.S.U.K. Congress in London, one was not struck by any feeling that his spirit was affected. He remained cheerful, alert, and keenly interested in all that was happening in the ophthalmological world.

Goulden was an ophthalmic surgeon of eminence in every way, a skilful and neat operator, a good diagnostician and a valuable opinion on any sort of case. His translation of Koby's text-book on the slit-lamp in collaboration with Clara Harris, and an exceedingly good book on "The Refraction of the Eye" were his major literary works, but he contributed regularly and most valuably to the Transactions of the O.S.U.K. and to the Proceedings of the Ophthalmic Section of the Royal Society of Medicine, of which Section he was also President. He always kept closely in touch with Continental ophthalmology and his readiness to adopt methods from abroad was well shown by his advocacy of Wheeler's operation which he made peculiarly his own.

Goulden was a steadfast and loyal friend, he had a great sense of justice and right action and reacted vigorously to anything which he thought unfair or unjust. He will be remembered with respect for his valuable services to ophthalmology and most affectionately by his friends who admired him so much.

M. WHITING. 